\title{
Phytoalexin Production in an Apple Cultivar Resistant to Venturia inaequalis
}

\author{
Geza Hrazdina, Wlodzimierz Borejsza-Wysocki, and Cathy Lester
}

First and second authors: Department of Food Science and Technology, Cornell University, Geneva, NY 14456; and third author: Department of Organic Chemistry, Cornell University, Ithaca, NY 14853.

Accepted for publication 13 May 1997.

\begin{abstract}
Hrazdina, G., Borejsza-Wysocki, W., and Lester, C. 1997. Phytoalexin production in an apple cultivar resistant to Venturia inaequalis. Phytopathology 87:868-876.

Cell suspension cultures of the scab-resistant apple (Malus $\times$ domestica) cultivar Liberty were challenged with yeast extract to mimic the effect of biological stress such as fungal invasion. The cells responded to the challenge by production of novel compounds. Suspension cultures of the scab-susceptible cultivar McIntosh, when similarly challenged, showed no detectable response. The major compound produced by scab-resistant cells in response to the challenge has been identified as the 2,4-methoxy-

3-hydroxy-9-O- $\beta$-D-glucosyloxydibenzofuran by UV, mass spectrometry, ${ }^{1} \mathrm{H}$-nuclear magnetic resonance (NMR), and ${ }^{13} \mathrm{C}$-NMR spectroscopy. We suggest the trivial name malusfuran for the compound. Malusfuran production was initiated approximately $24 \mathrm{~h}$ after being challenged. Malusfuran inhibited spore germination and growth of Venturia inaequalis at millimolar concentrations, indicating its role as a possible phytoalexin. The aglycone of malusfuran, 2,4-methoxy-3,9-hydroxy-dibenzofuran, showed higher toxicity to $V$. inaequalis than to the parent malusfuran. In vitro cultures of $V$. inaequalis produced a $\beta$-glucosidase that hydrolyzed ortho- and para-substituted nitrophenyl- $\beta$-glucosides, suggesting that the aglycone may act as the actual phytoalexin.
\end{abstract}

Resistance of apple (Malus $\times$ domestica Borkh.) cultivars to Venturia inaequalis (Cooke) G. Wint., the organism causing apple scab, has been investigated for over 100 years $(1,54)$. Commercially produced apple cultivars resistant to scab carry the $V f$ resistance derived from Malus floribunda $821(22,23,30)$, an ornamental crab apple variety. Although $V f$ has been proven to provide resistance against five different races of the fungus, there are indications that this resistance is being circumvented by some fungal strains (40). Therefore, a detailed investigation on the resistance mechanism of $V$. inaequalis seems to be timely. Although much effort was extended in the past to determine the differences in chemical composition between susceptible and resistant host tissues, there is no consensus about the identity of the chemicals that are responsible for resistance (33). The chemical group receiving the most attention was the phenolic compounds. Phenolic metabolism has often been linked to disease resistance in other species, and it was expected that this will also hold for the genus Malus. Kirkham's (25) investigation on water-soluble metabolites extracted from apple cultivars exhibiting different levels of resistance was inconclusive. The major phenolic components did not differ significantly among the different cultivars, nor was there any difference between young and old leaves. Although a phenolic fraction was inhibitory to the growth and sporulation of $V$. inaequalis, the degree of inhibition did not correlate with the relative susceptibility or resistance of the cultivars.

Investigations in other laboratories showed that the major phenolic compound of apple extracts was phloridzin, a dihydrochalcone glycoside (21). Studies following its original identification provided suggestive evidence that the presence of this compound in apples was related to resistance against Venturia. The evidence was based on observations that phenylalanine was concentrated around

Corresponding author: G. Hrazdina; E-mail address: gh10@ cornell.edu

Publication no. P-1997-0623-01R

(C) 1997 The American Phytopathological Society the infection site in the early stages of invasion; the fungus was able to degrade phloridzin to its aglycone phloretin, which was toxic; leaf homogenates underwent enzymatic browning, and progressive browning gradually inhibited the fungus; and labeled phenylalanine was incorporated into phloridzin (33). These investigations, however, addressed the constitutively produced compounds in apple tissues and were not focusing specifically on phytoalexins, compounds that are produced in response of plant tissues to pathogen attack or various abiotic stresses. Genetic experiments were also carried out to map the location of the resistance genes in the genome of Malus $(17,24,49)$; however, to date, they did not contribute to our general understanding of the disease-resistance principle.

We have established a model system to investigate the biochemistry and genetics of the resistance mechanism of apple cultivars against $V$. inaequalis. Here, we report the establishment of cell suspension cultures of a susceptible and a resistant cultivar and their response to treatment with yeast extract. Also, we report the structure of the major compound produced by the resistant cultivar and its effect on the fungus.

\section{MATERIALS AND METHODS}

Cell suspension cultures. Primary callus cultures were initiated from approximately 2-month-old apical shoot pieces of 'McIntosh' (scab susceptible) and 'Liberty' (scab resistant) apple plants on Murashige-Skoog (MS) basal salt medium (37) supplemented with $9.0 \mu \mathrm{M}$ 2,4-dichlorophenoxyacetic acid, $4.9 \mu \mathrm{M}$ indole-3butyric acid, $0.5 \mu \mathrm{M}$ kinetin, $0.555 \mathrm{mM}$ myo-inositol, $4.1 \mu \mathrm{M}$ nicotinic acid, $2.4 \mu \mathrm{M}$ pyridoxine hydrochloride, $0.3 \mu \mathrm{M}$ thiamine hydrochloride, $87.7 \mathrm{mM}$ sucrose, and $8 \mathrm{~g} /$ liter of Difco Biotec agar (Difco Laboratories, Detroit). Shoots (approximately $5 \mathrm{~cm}$ in length) were sterilized with mercuric chloride similarly to that reported earlier for raspberries (6). Secondary calli were initiated from primary callus tissues. Calli were subcultured at 3-week intervals and propagated in the dark at $25^{\circ} \mathrm{C}$. Friable, soft calli were selected for the initiation of cell suspension cultures. Suspension cultures were started by shaking $80 \mathrm{~g}$ of calli at $150 \mathrm{rpm}$ in 
$500 \mathrm{ml}$ of the above liquid medium (without agar) in 4-liter Erlenmeyer flasks. Cultures were shaken $(120 \mathrm{rpm})$ in the dark at $25^{\circ} \mathrm{C}$. Cells were harvested at 7 - to 10 -day intervals by filtering the suspension through a 60-mesh screen and transferred to fresh medium.

Cell growth in the culture was characterized by determining wet and dry cell weights, sucrose concentration, and conductivity.

Elicitation of cells. Yeast extract ( $3 \mathrm{~g} /$ liter [Difco Laboratories] and $170 \mathrm{mg} /$ liter of glucose equivalent), which was reported to act as an elicitor $(19,41,48)$, was added to 7-day-old cells $(100 \mathrm{~g})$ that were in the linear growth phase and incubated in the dark. Cells were harvested in 6- to 24-h intervals by filtration, frozen in liquid nitrogen, and stored at $-100^{\circ} \mathrm{C}$. Media were also frozen and stored at $-100^{\circ} \mathrm{C}$.

A $V$. inaequalis elicitor preparation $(17 \mathrm{mg} / 100 \mathrm{ml}$ of cell suspension) that was made according to Messner et al. (36), and contained approximately the same glucose equivalent as the yeast extract, was added to the cell cultures as above. Cells were processed and stored as described.

Monitoring of changes in metabolism of the cell cultures. Cells $(2.0 \mathrm{~g})$ were extracted twice with $4 \mathrm{ml}$ of $\mathrm{MeOH}$, the solvent removed under reduced pressure, the residue reextracted with ethyl acetate, and the ethyl acetate dried over $\mathrm{Na}_{2} \mathrm{SO}_{4}$ and evaporated to dryness. The residue was dissolved in $1.0 \mathrm{ml}$ of $\mathrm{MeOH}$, filtered through a $0.45-\mu$ filter (Gelman Sciences Inc., Ann Arbor, MI), and used for high-pressure liquid chromatography (HPLC) analysis by reverse phase $\mathrm{C} 18 \mu$ Bondapack column $(4.6 \times 250 \mathrm{~mm}$; Alltech Assoc. Inc., Deerfield, IL) using a linear gradient of 30 to $80 \%$ aqueous acetonitrile containing $4.4 \%$ formic acid $(0.83 \%$ increase/min). Twenty-five-microliter aliquots were used for HPLC analysis. The flow rate was $1.0 \mathrm{ml} / \mathrm{min}$, and separation was monitored at $280 \mathrm{~nm}$.

Media $(25 \mathrm{ml})$ were extracted with ethyl acetate $(2 \times 25 \mathrm{ml})$, and the extracts were dried over $\mathrm{Na}_{2} \mathrm{SO}_{4}$ and processed as above.

Isolation of malusfuran. The compound with the retention time (Rt) of $16.5 \mathrm{~min}$ produced in the largest amount in response to elicitor treatment (after $96 \mathrm{~h}$ ) was extracted from the cell culture filtrate (1.0 liter) with ethyl acetate $(3 \times 500 \mathrm{ml})$, and the ethyl acetate layer was dried with $\mathrm{Na}_{2} \mathrm{SO}_{4}$ and evaporated to dryness. The residue was purified by precipitation or by separation on thin-layer chromatography (TLC) in solvent C (described below). Malusfuran was precipitated from acetone by addition of two volumes of hexane at $4^{\circ} \mathrm{C}$. The precipitate was filtered, dried under vacuum, and dissolved in methanol. After TLC separation in solvent $\mathrm{C}$, malusfuran $\left(\mathrm{R}_{f}=0.78\right)$ was eluted from silica gel with methanol and dried under vacuum.

Acidic and enzymatic hydrolysis of malusfuran. A sample of malusfuran $(12.5 \mathrm{mg}$ ) purified by TLC in solvent C (described below) was dissolved in $250 \mu \mathrm{l}$ of methanol. Ten milliliters of $1 \mathrm{M}$ $\mathrm{HCl}$ was added, and the mixture was refluxed for $1 \mathrm{~h}$. The hydrolysate was allowed to cool to room temperature and extracted with four volumes of ethyl acetate. The ethyl acetate phase was dried over anhydrous $\mathrm{Na}_{2} \mathrm{SO}_{4}$ and filtered, and the filtrate evaporated to dryness. The residue was dissolved with $500 \mu \mathrm{l}$ of methanol and purified by TLC in solvent B (described below). The major compound $\left(\mathrm{R}_{f} 0.43\right)$ was eluted from silica gel with methanol and dried under vacuum. Yield was $6.5 \mathrm{mg}$. An aliquot of this preparation was used for the fungitoxicity experiments.

The aqueous phase was neutralized to $\mathrm{pH} 7.0$ by addition of 1 $\mathrm{M} \mathrm{NaOH}$ and freeze-dried. The residue was dissolved in $5 \mathrm{ml}$ of water (HPLC grade) and filtered through a $0.45-\mu$ filter (Gelman Sciences Inc.), and a 10- $\mu$ l aliquot was subjected to HPLC analysis (Hewlett-Packard 1090; Hewlett-Packard Co., Avondale, PA) on Hypersil ODS (Hewlett-Packard Co.) and Aminex HPX-87H (Bio-Rad Laboratories, Rockville Centre, NY) columns. Separation was with $20 \%$ acetonitrile in $0.5 \mathrm{mM}$ aqueous $\mathrm{H}_{2} \mathrm{SO}_{4}$ at 0.6 $\mathrm{ml} / \mathrm{min}$. Detection of glucose was by refractive index (HP 1037A refractive index detector; Hewlett-Packard Co.).
Enzymatic hydrolysis was carried out with a $\beta$-glucosidase preparation from almond (Sigma Chemical Co., St. Louis). Malusfuran $(0.4 \mathrm{mg})$ was dissolved in $20 \mu \mathrm{l}$ of ethanol and mixed with $230 \mu \mathrm{l}$ of acetate buffer $(0.1 \mathrm{M}, \mathrm{pH} 5.0)$. $\beta$-Glucosidase $(2.0 \mathrm{mg})$ was dissolved in $250 \mu \mathrm{l}$ of acetate buffer $(0.1 \mathrm{M}, \mathrm{pH} 5.0)$ and added to the malusfuran solution. The mixture was incubated at $37^{\circ} \mathrm{C}$ and sampled at 12 - and 24 -h intervals. Samples $(200 \mu \mathrm{l})$ were extracted with four volumes of ethyl acetate, the ethyl acetate extract evaporated to dryness, and the residue dissolved in 50 $\mu \mathrm{l}$ of methanol and analyzed by TLC.

TLC. TLC was carried out on silica gel plates $(20 \times 20 \mathrm{~cm}$; Sigma Chemical Co.) containing fluorescent indicator. The following solvent systems were used: chloroform/acetone (19:1), hexane/ethyl acetate/methanol (60:40:1) (29), sec.butyl alcohol/acetic acid/water (70:2:28), and acetic acid/water (2:98) (38). Dry chromatograms were viewed under UV (254 and $360 \mathrm{~nm})$ for identification.

UV spectra. UV spectra were recorded in $\mathrm{MeOH}$ and $\mathrm{MeOH}$ MeONa using a Bausch and Lomb Spectronic 2000 spectrophotometer (Bausch \& Lomb Inc., Rochester, NY).

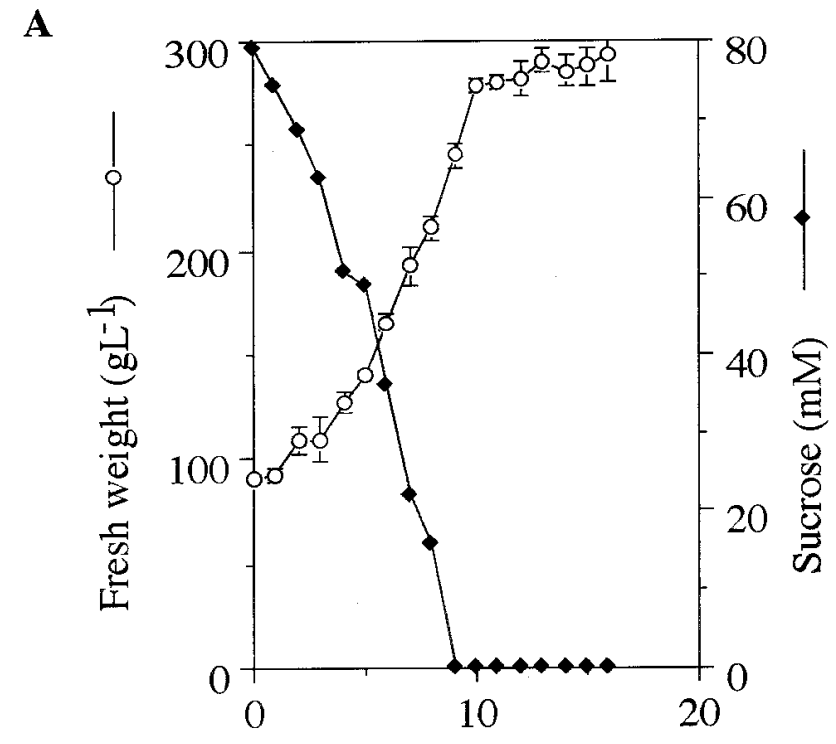

B

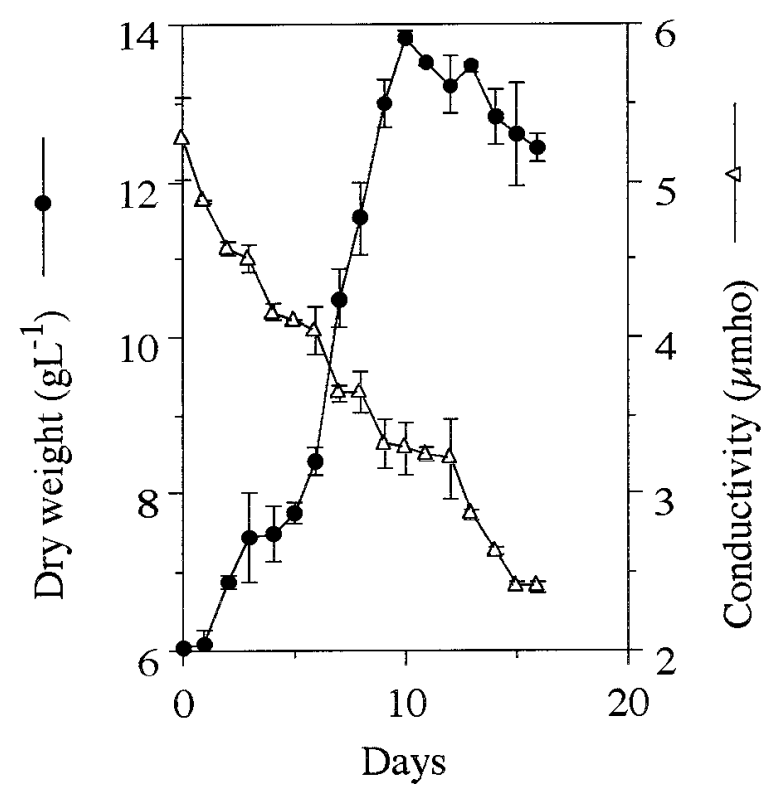

Fig. 1. Changes in fresh weight, dry weight, sucrose, and conductivity of cell suspension cultures of apple cultivar Liberty. Experimental details are given in Materials and Methods. Bars indicate \pm standard error. 
Mass spectrometry. Gas chromatography-mass spectrometric analysis was carried out on a Hewlett-Packard 5970 GC-MS as previously described (5) (Hewlett-Packard Co.).

Nuclear magnetic resonance (NMR) analysis. One- and twodimensional homonuclear ${ }^{1} \mathrm{H}-\mathrm{NMR}$ and gradient-enhanced ${ }^{1} \mathrm{H},{ }^{13} \mathrm{C}$ heteronuclear multiple-quantum coherence (HMQC) and heteronuclear multiple-bond correlation (HMBC) spectrometry $(20,45)$ were performed on a Varian Unity 500 spectrometer (Varian, Sunnyvale, CA) operating at $499.93 \mathrm{MHz}$ for proton and $125.72 \mathrm{MHz}$ for carbon. ${ }^{13} \mathrm{C}\left[{ }^{1} \mathrm{H}\right]$ one-dimensional and distortionless enhancement by polarization transfer (DEPT) NMR experiments were performed on a Varian VXR-400S spectrometer (Varian) operating at $100.56 \mathrm{MHz}$ for carbon.
Determination of fungitoxicity. Fungitoxicity of malusfuran and its aglycone was determined using conidia-spore suspension and mycelium of $V$. inaequalis.

Four hundred microliters of a spore suspension containing approximately $2 \times 10^{5}$ spores per milliliter was mixed with $100 \mu \mathrm{l}$ of an aqueous solution of malusfuran or the aglycone (previously dissolved in $10 \mu \mathrm{l}$ of ethanol) to give final concentrations of 0.125 , $0.25,0.5,0.75$, and $1.00 \mathrm{mM}$. One hundred microliters of this spore mixture was placed in each well of Corning-Cell Well plates (Corning Glass Inc., Corning, NY), covered with cover glasses, and incubated in the dark at $25^{\circ} \mathrm{C}$. Both germinated and ungerminated spores were counted under the microscope, and percent inhibition was calculated from the actual spore germination rate in
A

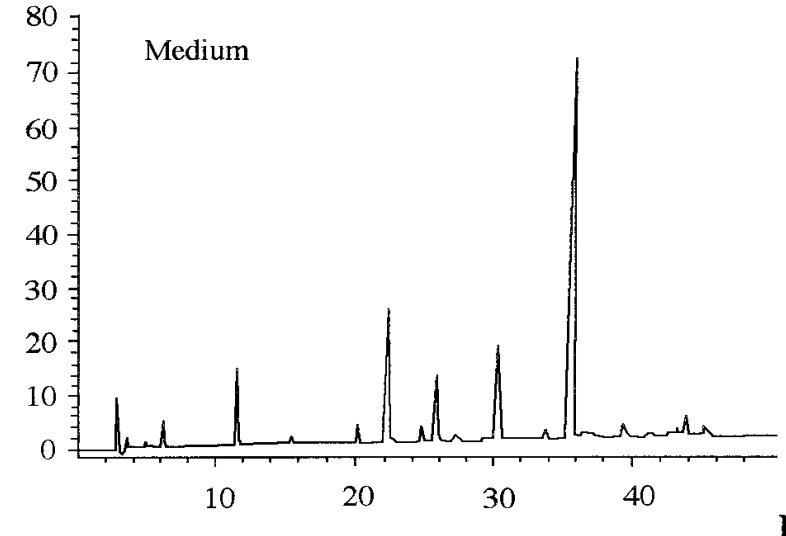

C

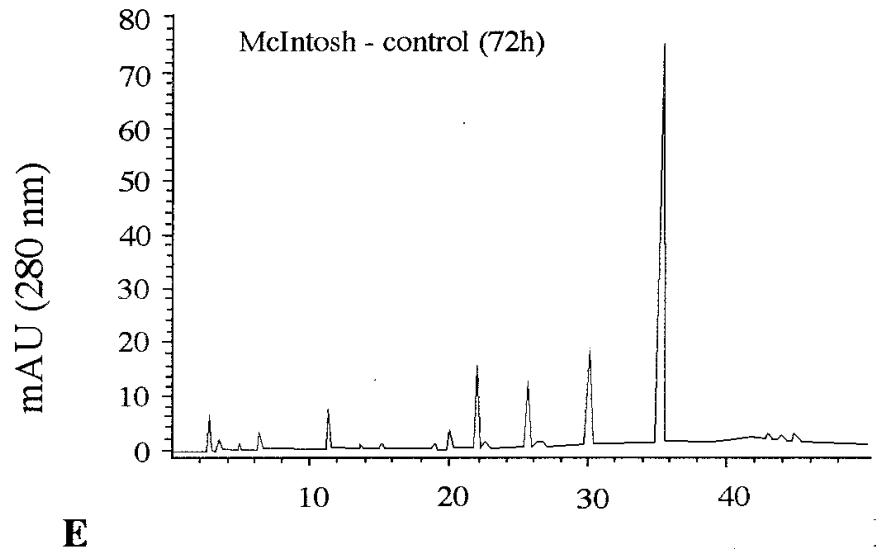

$\mathbf{E}$

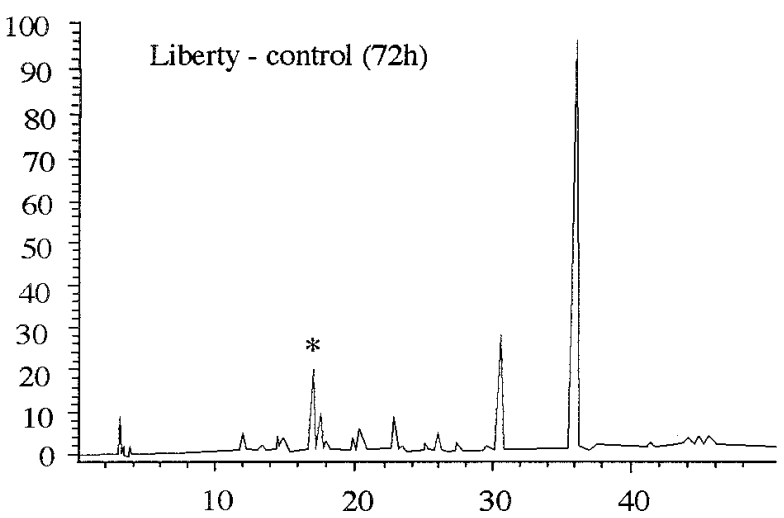

B

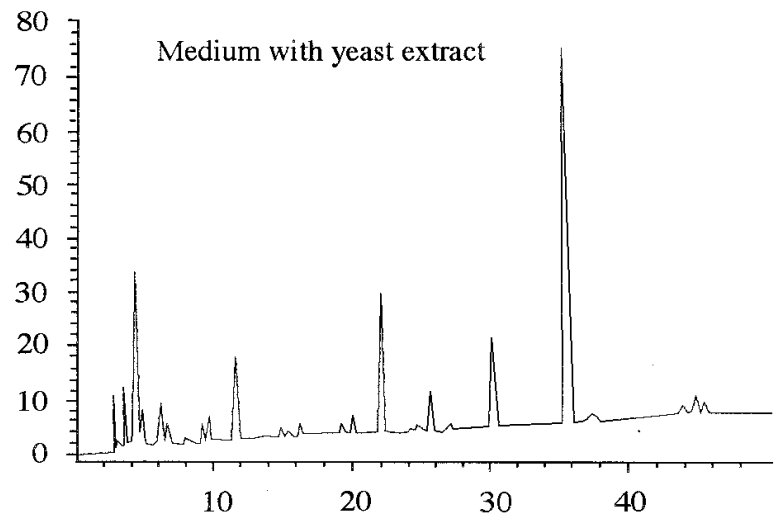

D

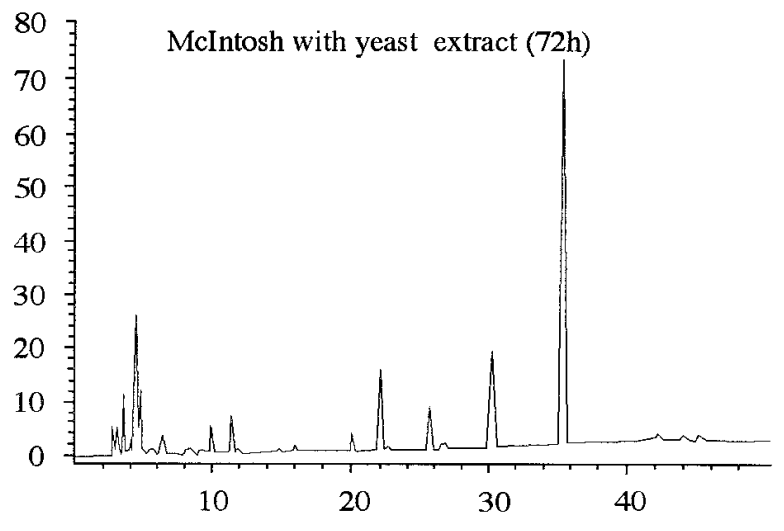

$\mathbf{F}$

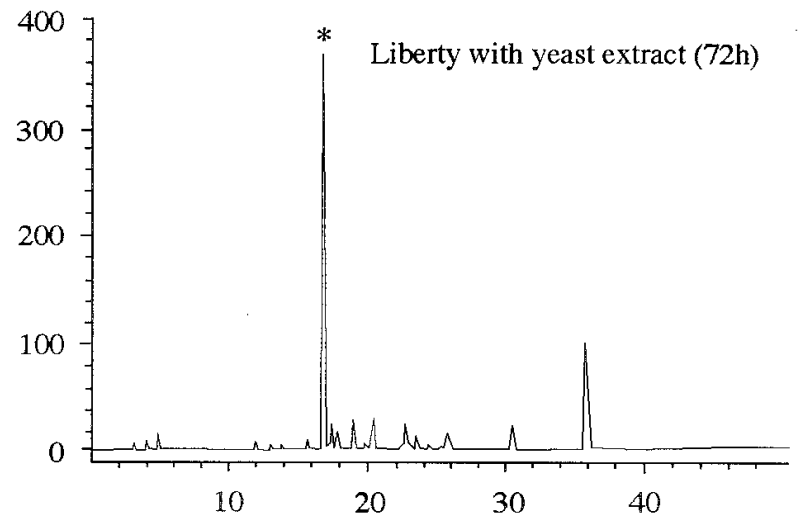

Peak retention time (min.)

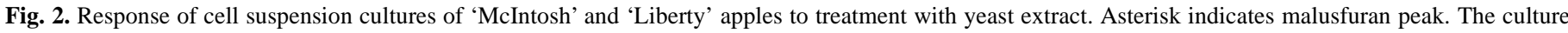

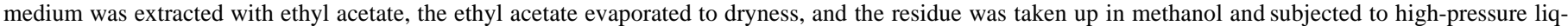
uid chromatography analysis as described in Materials and Methods. Note scale difference in $\mathbf{F}$. 
water and in the presence of malusfuran or the aglycone. Spores were classified as germinated when the length of the germ tube was at least twice the length of the spore. Standard error was calculated from four replications (at least 100 spores per replication).

The effect of malusfuran and its aglycone on the mycelial growth of $V$. inaequalis was determined on potato dextrose agar (PDA) medium (Difco Laboratories) in sterile Corning-Cell Well plates (22.6 mm well diameter; Corning Glass Inc.). Different amounts of malusfuran or the aglycone were dissolved in $10 \mu \mathrm{l}$ of ethanol and mixed with $90 \mu \mathrm{l}$ of sterile water. These solutions were added to $900 \mu \mathrm{l}$ of sterile liquid PDA medium (at $50^{\circ} \mathrm{C}$ ) and mixed thoroughly before solidification. Final concentration of malusfuran or its aglycone was determined as in the spore germination experiments described above. Mycelial discs $(5 \mathrm{~mm})$ of 21day-old $V$. inaequalis cultures were placed in the center of the wells, and colony diameters were measured after 7 days of growth at $21^{\circ} \mathrm{C}$. Mean colony diameter \pm standard error was calculated from four replications.

$\boldsymbol{V}$. inaequalis cultures. Liquid fungal cultures were started by inoculating $100 \mathrm{ml}$ of potato dextrose broth (PDB) medium (Difco Laboratories) with $5 \mathrm{ml}$ of a blended hyphal inoculum of $V$. inaequalis. Cultures were shaken at $150 \mathrm{rpm}$ in the dark at $21^{\circ} \mathrm{C}$. After 21 days of growth, hyphae were harvested by filtration, freezedried, and stored at $-100^{\circ} \mathrm{C}$. Medium obtained from fungal cultures was fractionated with saturated ammonium sulfate $(30,50$, and $80 \%$ saturation), and the precipitate was removed by centrifugation at $20,000 \times g$ for $20 \mathrm{~min}$. The protein fraction obtained from the $80 \%$ ammonium sulfate saturation was resuspended in 5 $\mathrm{ml}$ of acetate buffer (0.1 M, pH 5.0), desalted on Bio-Gel P-6 gelfiltration column (Bio-Rad Laboratories, Richmond, CA), freezedried, and stored at $-100^{\circ} \mathrm{C}$.

Determination of $\beta$-glucosidase activity in $V$. inaequalis. Freeze-dried hyphae of $V$. inaequalis $(100 \mathrm{mg})$ were homogenized in $3.0 \mathrm{ml}$ of acetate buffer $(0.1 \mathrm{M}, \mathrm{pH} 5.0)$, and the resulting slurry was centrifuged for $5 \mathrm{~min}$ at $11,000 \times \mathrm{g}$. Five hundred-microliter aliquots of the supernatant were incubated with $500-\mu 1$ portions of either a $4 \mathrm{mM}$ solution of $o$ - or $p$-nitrophenyl- $\beta$-D-glucoside prepared in $0.1 \mathrm{M}$ acetate buffer, $\mathrm{pH} 5.0$, at $37^{\circ} \mathrm{C}$ overnight. The reaction was monitored by following the increase in absorbance at $400 \mathrm{~nm}$ ( $p$-nitrophenyl glucoside) or $420 \mathrm{~nm}$ (o-nitrophenyl glucoside) in a spectrophotometer. Enzyme activity in the growth medium was measured similarly with $500 \mu \mathrm{l}$ of substrate solution in $0.1 \mathrm{M}$ acetate buffer, $\mathrm{pH} 5.0$, and $5 \mathrm{mg}$ of freeze-dried protein preparation (described above) dissolved in $500 \mu \mathrm{l}$ of the same buffer.

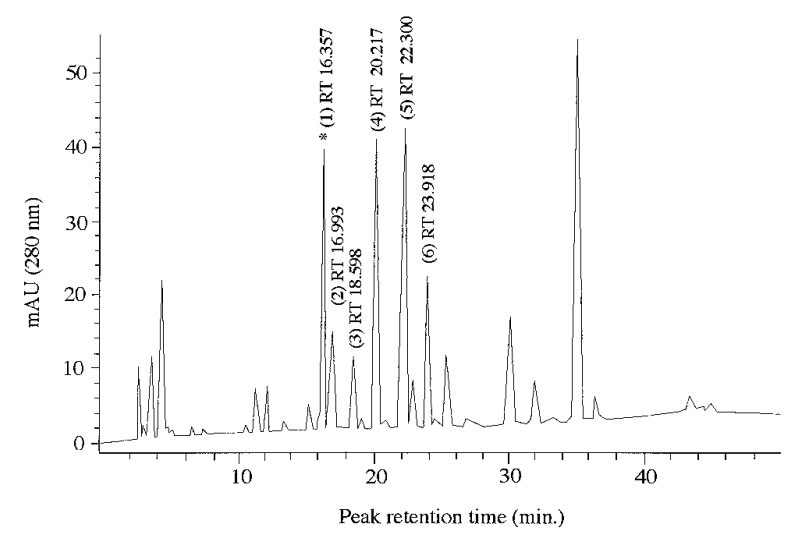

Fig. 3. High-pressure liquid chromatogram after $24 \mathrm{~h}$ of a yeast extracttreated 'Liberty' (scab resistant) cell suspension culture. The culture medium was extracted with ethyl acetate and the extract evaporated to dryness, dissolved in methanol, and subjected to high-pressure liquid chromatography analysis as described in Materials and Methods. Peak 1, marked with asterisk, is malusfuran.

\section{RESULTS}

Establishment of cell suspension cultures. Visible, primary calli formed on original explants after approximately 3 weeks. Primary calli were removed after an additional 2 weeks, dissected, and transferred to fresh medium (secondary calli). Both 'Liberty' and 'McIntosh' formed light yellow, compact (hard), and friable (soft) calli. Soft calli contained mostly round or somewhat elongated cells with thin cell walls and large vacuoles. Soft calli were preferentially selected and subcultured at 3-week intervals for a period of 1 year. When these calli were agitated in liquid MS medium, they readily dispersed and formed a suspension that was composed mainly of single cells and small cell aggregates. The cell aggregates in the 'McIntosh' suspension were somewhat larger that those of 'Liberty'. Growth rates of both 'McIntosh' and 'Liberty' cells were similar and showed a threefold increase in fresh weight every 10 days. The suspension cultures were characterized by measuring changes in wet and dry weight of the cells, sucrose concentration, and conductivity of the media. Cell cultures propagated rapidly, and reached a linear growth phase after a 24-h lag period (Fig. 1). During the linear growth phase, the fresh weight of the cells nearly tripled (Fig. 1A), while dry weight doubled (Fig. 1B). The cells used up all available sucrose (Fig. 1A), and conductivity of the medium decreased from 5.3 to $2.3 \mu \mathrm{S}$ (Fig. 1B), showing significant changes in cation composition and concentration. When cells were left in the same medium for a longer time (14 days), the color of the suspension changed from light yellow to dark yellow-gray. The cells reached optimal growth conditions when transferred to fresh media at 7- to 9-day intervals.

Response of susceptible and resistant cells to yeast extract treatment. Six compounds were observed during HPLC separation in the ethyl acetate extracts from both the susceptible ('McIn-

TABLE 1. Chromatographic, UV-vis, and mass spectral properties of malusfuran

\begin{tabular}{lll}
\hline Property & Malusfuran & Aglycone \\
\hline $\mathrm{R}_{f}$ values in & & \\
Solvent A & 0 & 0.35 \\
Solvent B & 0 & 0.43 \\
Solvent C & 0.78 & 0.87 \\
Solvent D & 0.79 & 0.13 \\
$\lambda$ max in MeOH (E) & $263 \mathrm{~nm}(9,100)$ & $266 \mathrm{~nm}(3,100)$ \\
& $287 \mathrm{~nm}(9,900)$ & $284 \mathrm{~nm}(2,800)$ \\
& $302 \mathrm{~nm}, \mathrm{sh}^{\mathrm{a}}(6,600)$ & $304 \mathrm{~nm}, \mathrm{sh}(1,900)$ \\
$m / z$ & $314 \mathrm{~nm}(7,000)$ & $316 \mathrm{~nm}(2,600)$ \\
\hline
\end{tabular}

a $\mathrm{sh}=$ shoulder.

TABLE 2. ${ }^{1} \mathrm{H}$ and ${ }^{13} \mathrm{C}$ chemical shift assignments for malusfuran in dimethyl sulfoxide (DMSO)- $\mathrm{d}_{6}$ and acetone- $\mathrm{d}_{6}$

\begin{tabular}{lcccc}
\hline Position & $\mathrm{d}\left({ }^{\mathrm{l}} \mathrm{H}\right)^{\mathrm{a}}$ & $\mathrm{d}\left({ }^{13} \mathrm{C}\right)^{\mathrm{a}}$ & $\mathrm{d}\left({ }^{\mathrm{l}} \mathrm{H}\right)^{\mathrm{b}}$ & $\mathrm{d}\left({ }^{13} \mathrm{C}\right)^{\mathrm{b}}$ \\
\hline 1 & 7.50 & 101.2 & 7.64 & 101.3 \\
2 & & 147.4 & & 146.6 \\
3 & & 140.3 & & 140.4 \\
4 & & 134.2 & & 133.7 \\
$4 \mathrm{a}$ & 143.7 & & 143.8 \\
$5 \mathrm{a}$ & & 157.8 & & 158.0 \\
6 & 7.29 & 106.7 & 7.25 & 106.4 \\
7 & 7.30 & 127.7 & 7.31 & 127.1 \\
8 & 7.11 & 110.3 & 7.11 & 110.2 \\
9 & & 153.7 & & 153.7 \\
$9 \mathrm{a}$ & & 116.3 & & 116.2 \\
$9 \mathrm{~b}$ & & 115.8 & & 115.2 \\
2-OMe & 3.89 & 57.8 & 3.90 & 57.2 \\
4-OMe & 3.99 & 61.8 & 4.11 & 61.1 \\
3-OH & 9.00 & 140.3 & 7.81 & 140.0 \\
\hline
\end{tabular}

${ }^{a}$ Chemical shifts are referenced to trimethylsilane by assigning the solvent resonances to $2.50 \mathrm{ppm}$ for DMSO- $\mathrm{d}_{6}$.

${ }^{\mathrm{b}}$ Chemical shifts are referenced to trimethylsilane by assigning the solvent resonances to $2.05 \mathrm{ppm}$ for acetone- $\mathrm{d}_{6}$. 
tosh') and resistant ('Liberty') cell suspension cultures. Extraction of fresh culture medium resulted in the detection of the same six compounds, indicating that these were the components of the culture media (Fig. 2A and B). When susceptible cell cultures were treated with the yeast extract or the $V$. inaequalis elicitor prepara- tion, no new compounds could be detected in the ethyl acetate extracts, and HPLC traces remained identical to the untreated cell suspensions (Fig. 2C and D). However, when cell cultures of the resistant cultivar were treated with the yeast extract or the $V$. inaequalis preparation, the formation of new compounds was de-
$\mathbf{A}$

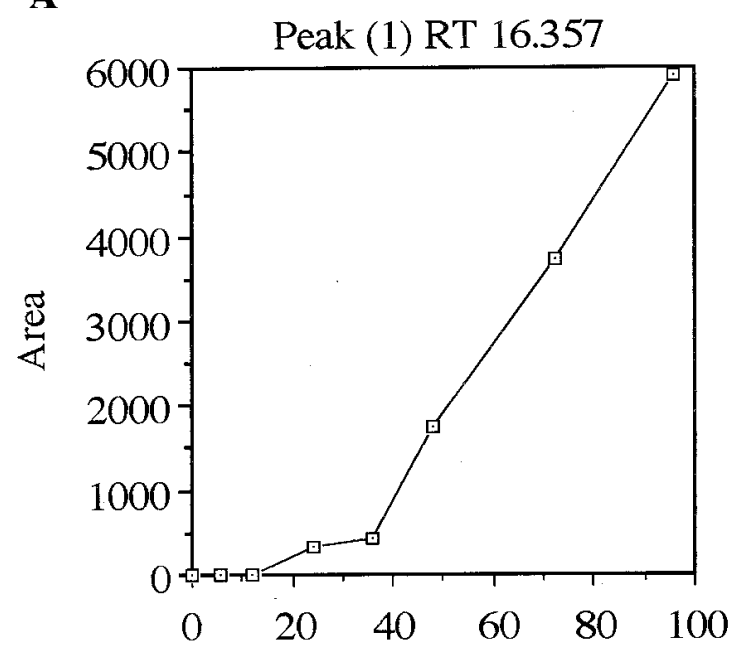

$\mathbf{C}$

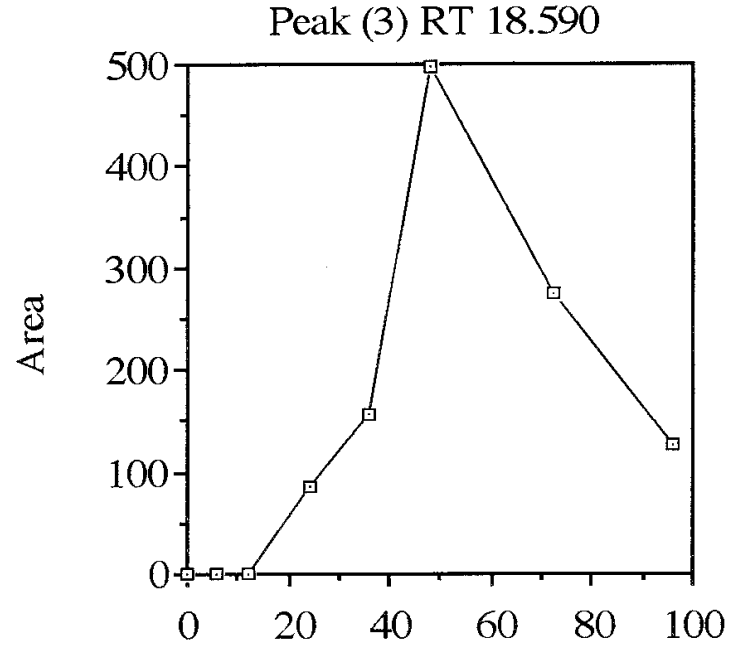

$\mathbf{E}$

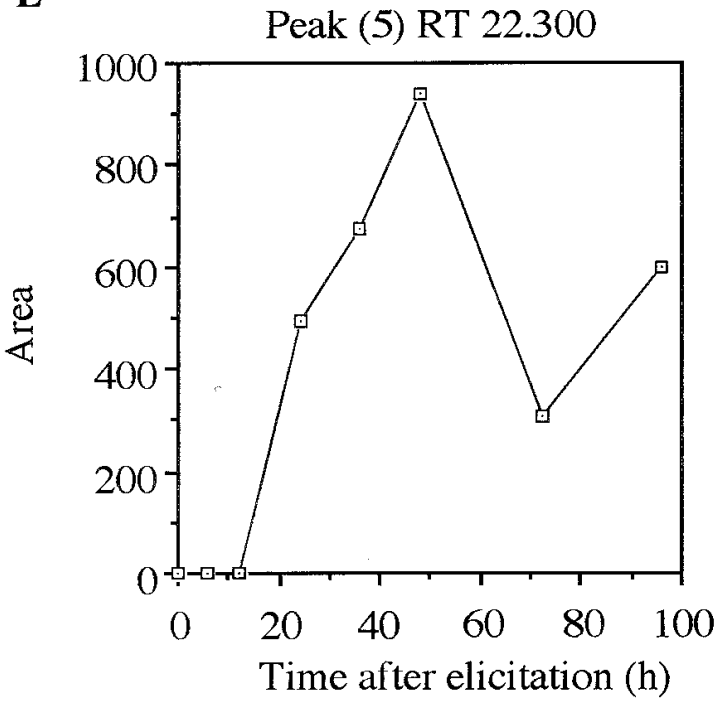

B

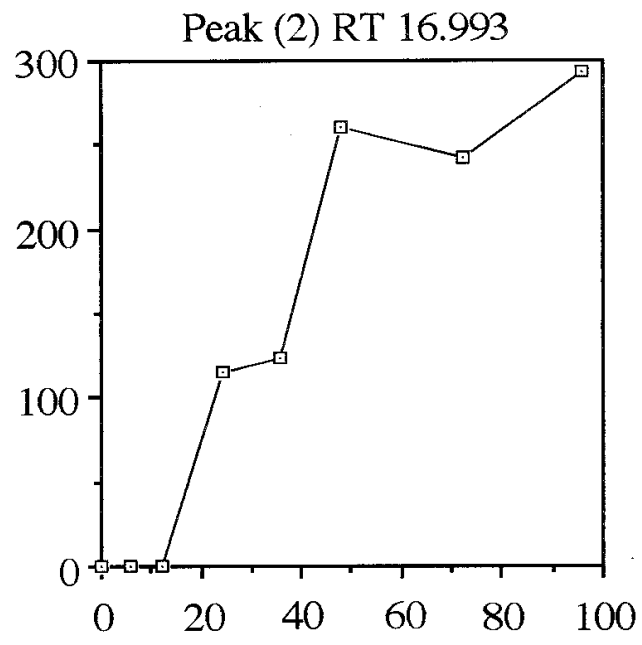

D

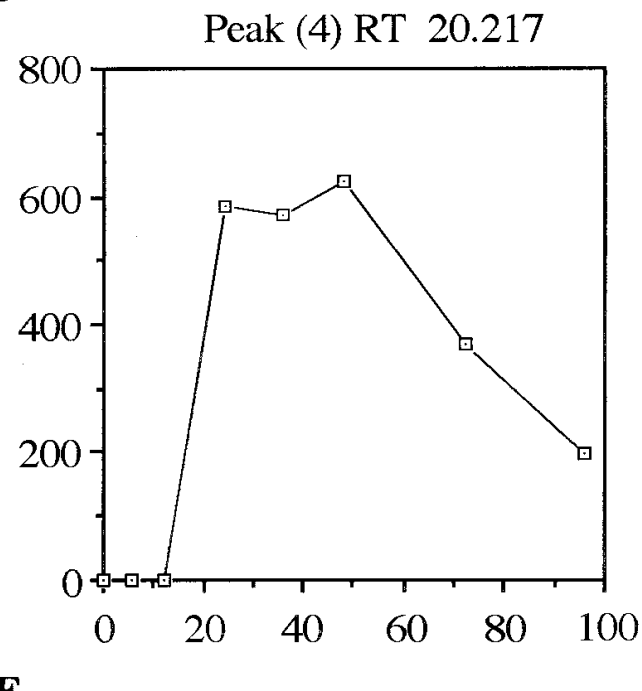

$\mathbf{F}$

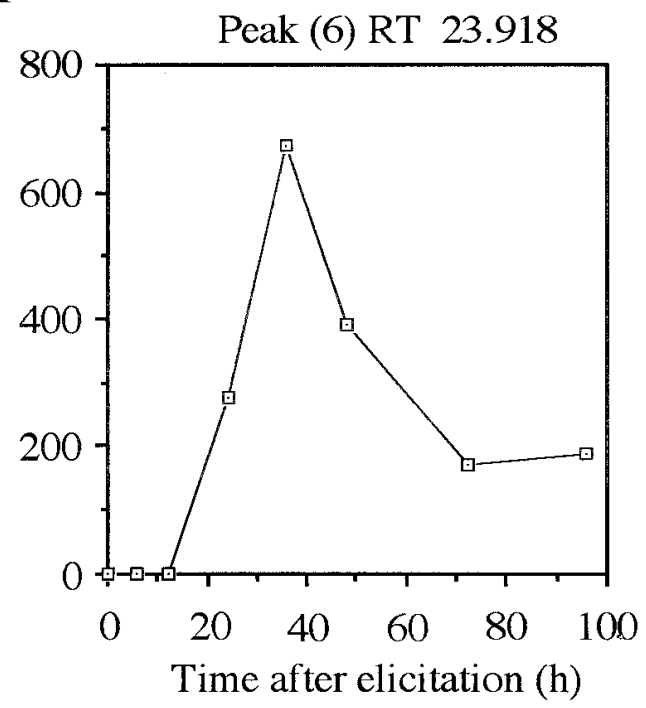

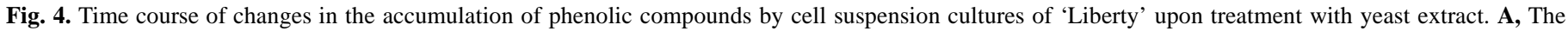
accumulation of malusfuran. B through $\mathbf{F}$, The identity of the compounds is not known. 
tected (Fig. 2E and F). Six new compounds were detected within $24 \mathrm{~h}$ after elicitor addition (Fig. 3). The concentration of the compounds with the Rt of $16.36 \mathrm{~min}$ and $16.99 \mathrm{~min}$ increased throughout the 96-h duration of the experiment (Fig. 4A and B), while that of the compounds with the Rt of 18.6, 20.2, 22.3, and 23.9 was transient, and decreased after a 48 -h period (Fig. 4C, D, E, and F). The concentration of the compound with the Rt of 16.36 min increased over 17 -fold in the 24- to 96 -h period following the addition of yeast extract (Fig. 4A). This was the major compound excreted into the growth medium by the scab-resistant cell suspension cultures (Fig. 2F). Therefore, for the isolation of this major compound, yeast extract-treated cell suspension cultures were used.

Identification and characterization of malusfuran. The major compound produced upon yeast extract treatment of $V$. inaequalisresistant cell suspension cultures was isolated and identified by $\mathrm{UV}$, mass spectrometry, ${ }^{1} \mathrm{H}-\mathrm{NMR}$ and ${ }^{13} \mathrm{C}-\mathrm{NMR}$ spectroscopy and spectrometry, and acidic and enzymatic hydrolysis. These data are shown in Tables 1 and 2. Detection at $280 \mathrm{~nm}$ and absorbance peaks at 263 and 287, with pronounced shoulders at 302 and $314 \mathrm{~nm}$ (Table 1), indicated that the compound was aromatic and most likely did not contain a flavonoid skeleton. The dual peaks at 263 and $287 \mathrm{~nm}$ were indicative of two aromatic rings with different substitution patterns. The relatively low absorption values of the compound further indicated a nonflavonoid nature (32). Mass spectral data indicated a molecular ion at $260 \mathrm{~m} / \mathrm{z}$ and that the compound contained three rings and six double bonds (35). The presence of low abundance mass ions at higher $\mathrm{m} / \mathrm{z}$ numbers indicated that the compound was conjugated with either sugar(s) or organic acid(s).

Acidic hydrolysis of the compound resulted in the production of a faster migrating spot on thin-layer chromatograms in apolar solvents $\left(\mathrm{R}_{f}=0.43\right.$ in solvent $\left.\mathrm{B}\right)$ that appeared as a dull dark spot under UV light. The same spot with an identical $\mathrm{R}_{f}$ value was produced when the compound was subjected to a $\beta$-glucosidase treatment, indicating that the parent compound was a glucoside. The presence of glucose in the hydrolysate as the sole sugar confirmed glucose as the sugar substituent in malusfuran.

The aglycone was isolated from acidic and enzymatic hydrolysates and subjected to mass spectrometric determination. The fragmentation pattern and molecular ion of the aglycone was identical to that obtained from the parent compound up to $\mathrm{M}^{+}$, but did not contain any higher $\mathrm{m} / \mathrm{z}$ fragments. This suggested that the parent compound was a glucoside with low volatility that decomposed under the gas chromatography-mass spectrometric conditions producing the volatile aglycone. The molecular ion and the fragmentation pattern of the aglycone suggested either a diphenolic or a dibenzofuran structure. ${ }^{1} \mathrm{H}$ and ${ }^{13} \mathrm{C}$ chemical shifts for the compound dissolved in dimethyl sulfoxide (DMSO) $-\mathrm{d}_{6}$ and acetone- $\mathrm{d}_{6}$ are listed in Table 2. The one-dimensional ${ }^{13} \mathrm{C}$ and DEPT spectra revealed that there were two methyl, one methylene, nine methine, and eight quaternary ${ }^{13} \mathrm{C}$ resonances. Four aromatic protons were identified in the one-dimensional ${ }^{1} \mathrm{H}$ spectrum. A doublet of doublets was observed at a chemical shift (d) of $7.11 \mathrm{ppm}$ for the compound dissolved in DMSO- $\mathrm{d}_{6}$ corresponding to $\mathrm{H}-8$, with an ortho coupling (3 JHH [vicinal homonuclear proton coupling constant $]=6.5 \mathrm{~Hz}$ ) with $\mathrm{H}-7$ at $\mathrm{d}=7.3 \mathrm{ppm}$ and a meta coupling

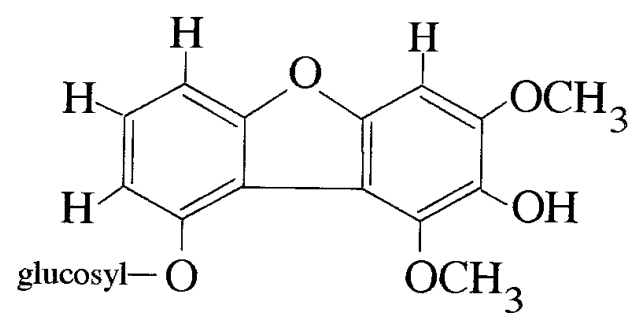

Fig. 5. Structure of malusfuran (2,4-methoxy-3-hydroxy-9-O- $\beta$-D-glucosyloxydibenzofuran).
( $3 \mathrm{JHH}=2.6 \mathrm{~Hz}$ ) with $\mathrm{H}-6$ at $\mathrm{d}=7.29 \mathrm{ppm}$. The fourth aromatic proton observed at $\mathrm{d}=7.50 \mathrm{ppm}$ was a singlet that was assigned to position 1 based on connectivities with four quaternary ${ }^{13} \mathrm{C}$ resonances in the HMBC spectrum.

The point of attachment for the glucose was identified from the HMBC and one-dimensional nuclear overhausen enhancement spectroscopy (NOESY) spectra. The carbon resonance at $\mathrm{d}=153.7 \mathrm{ppm}$ corresponded to the typical shift for a glucose-substituted benzene derivative (9) and displayed cross peaks with ${ }^{1} \mathrm{H}$ resonances at $\mathrm{d}=$ 5.10 (anomeric $1 \mathrm{H}$ ), 7.30, and $7.11 \mathrm{ppm}$. A splitting of $7.87 \mathrm{~Hz}$ for the anomeric signal verified that the linkage was $\beta$-glucosidic. A nuclear overhausen effect (NOE) between the anomeric ${ }^{1} \mathrm{H}$ and the aromatic singlet resonance at $\mathrm{d}=7.50 \mathrm{ppm}$ confirmed that the glucose moiety and the singlet occupied positions C-9 and C-1, respectively. The two methoxy and the hydroxy groups were assigned to the $\mathrm{C}-2, \mathrm{C}-4$, and $\mathrm{C}-3$ positions, respectively. An NOE between $\mathrm{H}-1$ and the methyl protons at $3.89 \mathrm{ppm}$ provided the assignment for the C-2 position for this methoxy group. A $3 \mathrm{JCH}$ (vicinal heteronuclear proton, carbon-13 coupling constant) $=6.6$ $\mathrm{Hz}$ for the cross peak $\left(\mathrm{d}\left[{ }^{1} \mathrm{H}\right]=7.5 \mathrm{ppm}, \mathrm{d}\left[{ }^{13} \mathrm{C}\right]=140.3 \mathrm{ppm}\right)$ in the HMBC spectrum placed the hydroxyl group in the $\mathrm{C}-3$ position (15). $\mathrm{A}{ }^{13} \mathrm{C}$ chemical shift of $\mathrm{d}=61.6 \mathrm{ppm}$ for the second methoxy group was shifted down field from typical values for ${ }^{13} \mathrm{C}$ resonances of methoxy substituents (55.0 to $56.5 \mathrm{ppm}$ ), suggesting that this group was di-ortho-substituted by two bulky substituents such as a hydroxy group, a methoxy group, or a ring junction, and must therefore, occupy the C-4 position (39).

Two NOEs with equal intensities observed between the hydroxyl proton and the methyl protons of each methoxy group confirmed the placement of the substituents for this ring. These data, together with those of UV, mass spectrometry, and enzymatic hydrolysis with a $\beta$-glucosidase preparation established the structure of the compound as the 2,4-methoxy-3-hydroxy-9-O- $\beta$-D-glucosyloxydibenzofuran (Fig. 5), for which the trivial name of "malusfuran" is suggested here.

Effect of malusfuran on spore germination and mycelium growth of $\boldsymbol{V}$. inaequalis. Since malusfuran was produced in large amounts upon elicitor treatment of the scab-resistant cells and it accumulated in the growth medium, it was expected to have physiological effects on either the spore germination or on the growth of the fungus. To investigate the possible antifungal effect of malusfuran, we germinated $V$. inaequalis spores both in the presence of

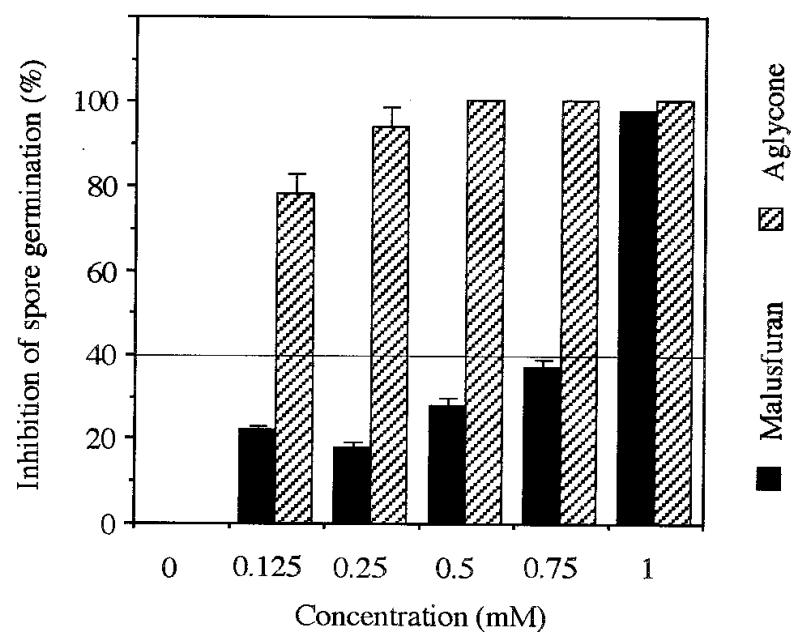

Fig. 6. Effect of increasing concentrations of malusfuran and its aglycone on spore germination of Venturia inaequalis after $24 \mathrm{~h}$. Bars indicate \pm standard error. The horizontal line indicates $40 \%$ inhibition of spore germination. Malusfuran or its aglycone was added in ethanol to spore suspensions $(2 \times$ $10^{5} / \mathrm{ml}$ ) of $\mathrm{V}$. inaequalis in water and incubated for $24 \mathrm{~h}$ at $22^{\circ} \mathrm{C}$. Ungerminated and germinated spores were counted, and inhibition was calculated as described in Materials and Methods. 
malusfuran and its aglycone at five different concentrations (Figs. 6 and 7). Malusfuran was slightly inhibitory to spore germination in the a concentration range of 0.125 to $0.5 \mathrm{mM}$. At a $0.75 \mathrm{mM}$ malusfuran concentration, an approximately $40 \%$ inhibition was observed, while a $1.0 \mathrm{mM}$ concentration resulted in a near full inhibition during the first $24 \mathrm{~h}$ of incubation. Although some spores started to germinate during this time period, germ tube elongation was arrested (Fig. 7). Approximately $60 \%$ of the spores in $1.0 \mathrm{mM}$ malusfuran containing medium started to germinate after $48 \mathrm{~h}$ of incubation, however, germ tube elongation was inhibited and tubes were much shorter than those in the control. Also, appressorium formation was inhibited to approximately $80 \%$ in the germinated spores.

The malusfuran aglycone had a more pronounced effect on spore germination and germ tube elongation than did malusfuran. At $0.125 \mathrm{mM}$ concentration, the aglycone showed an approximately $80 \%$ inhibition of spore germination, while higher concentrations $(0.25$ to $1.0 \mathrm{mM})$ showed a near complete $(94 \%)$ or complete (100\%) inhibition (Figs. 6 and 7). The effect of malusfuran and its aglycone on the mycelial growth of $V$. inaequalis is shown on Figure 8. Similar to the spore germination experiment, the mycelial growth of $V$. inaequalis was inhibited by both compounds. However, as with spore germination, the aglycone was more inhibitory than the parent compound, showing a $45 \%$ inhibition of mycelial growth at a $0.5 \mathrm{mM}$ concentration and near complete or complete inhibition at $1.0 \mathrm{mM}$. Malusfuran showed a $50 \%$ inhibition of mycelial growth at a $1.0 \mathrm{mM}$ concentration. Our data suggest that malusfuran may indeed serve as a phytoalexin that interferes with germination and growth of $V$. inaequalis at concentrations that are thought to be present at localized infection sites $(10,34)$. Because malusfuran had a significantly lesser effect on $V$. inaequalis than its aglycone, we suspected that the fungus had either a constitutive or an inducible $\beta$-glucosidase as part of its invading mechanism. The presence of hydrolytic enzymes during spore germination of $V$. inaequalis has been shown earlier (42). Incubation of both $o$ - and $p$-nitrophenyl- $\beta$-D-glucoside solutions with extracts from $V$. inaequalis hyphae confirmed the presence of a $\beta$-glucosidase that is capable of hydrolyzing both the $o$ - and $p$ substituted glucosides of nitrophenol (data not shown).

\section{DISCUSSION}

Resistance in apple cultivars against scab has been of interest to researchers for nearly 100 years $(1,54)$. Although investigations in the 1950 s to 1970 s focused strongly on metabolic changes in apple tissues associated with host-fungus interactions, there was no consensus concerning the structure of active components produced in response to fungal attack. A number of phenolic compounds such as phloridzin (21), leucoanthocyanidins, catechin derivatives, flavonols, anthocyanins, and chlorogenic acid isomers (8) were suggested to be part of the defense mechanism in scab-resistant cultivars (43,50-53). However, these compounds accumulated in both susceptible and resistant plants and did not fit the definition of "phytoalexins," antimicrobial compounds that accumulate as the result of abiotic or biotic stress. Some of the difficulties encountered in these early investigations were caused by the relative insensitivity of the available methodologies and, most likely, also by the choice of the plant material. Although phytoalexin concentrations at the infection site are most likely at millimolar levels, their concentration at the organ level (i.e., leaf or fruit) is most likely orders of magnitude lower $(34,47)$.

Cell suspension cultures have been successfully used in the past to investigate plant biochemical pathways $(2,7,18)$ and the underlying biochemical events in plant-microbe interactions $(4,11,12$, 16,31). The advantage of the cell cultures is that all or most cells respond to the treatment, and the resulting response is measurable both at the product and pathway level. Our investigation using cell suspension cultures of scab-susceptible ('McIntosh') and scab-resistant ('Liberty') apple cultivars clearly shows a differential response of the resistant cell cultures to yeast extract or $V$. inaequalis elicitor treatment. This differential response consists of the synthesis and accumulation of six new metabolites, one of them in large amounts. We have identified the metabolite produced

\section{Control}
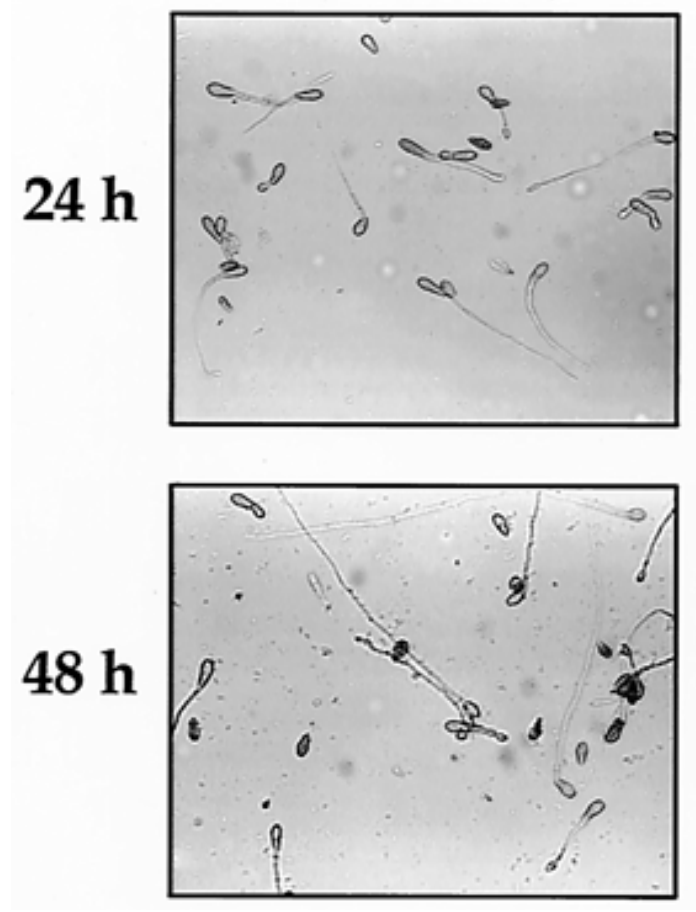

Malusfuran
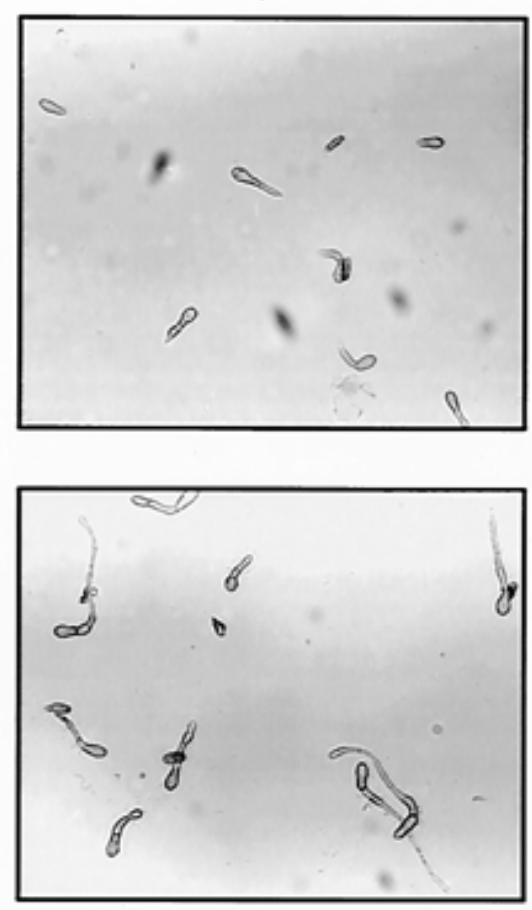

Aglycone
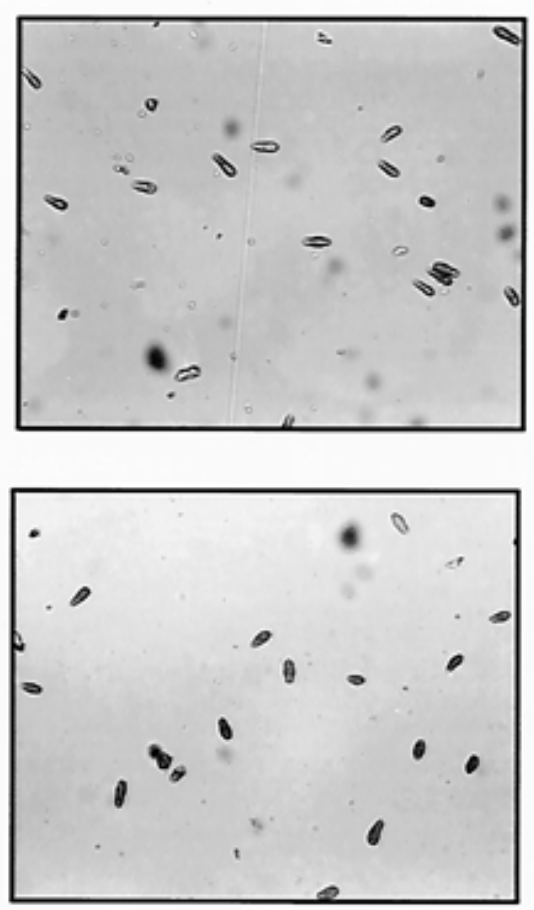

Fig. 7. Effect of malusfuran and its aglycone on spore germination and germ tube elongation of Venturia inaequalis. Ethanolic solutions of malusfuran and its aglycone were added at a $1 \mathrm{mM}$ concentration to spore suspensions of $V$. inaequalis and incubated for 24 and $48 \mathrm{~h}$ at $25^{\circ} \mathrm{C}$. Identical spore suspensions without addition of the compounds was used as a control (magnification $\times 125)$. 
in highest amount as 2,4-methoxy-3-hydroxy-9-O- $\beta$-D-glucosyloxydibenzofuran (malusfuran). Malusfuran fits the definition of a phytoalexin. It is produced upon treatment of the cells with an elicitor preparation, it accumulated during $96 \mathrm{~h}$ to a nearly $50 \mu \mathrm{M}$ concentration in the growth medium, and it is toxic to $V$. inaequalis at millimolar concentrations. Although the identity of malusfuran is reported here for the first time, the compound has most probably been observed previously by other investigators. Kirkham (25) reported the isolation of a fraction from $V$. inaequalis-infected apple leaves containing phenolic compounds that were strongly inhibitory to the growth and sporulation of the fungus. Similarly, a UV-fluorescent compound was also reported in $V$. inaequalis-infected, scab-resistant apple leaves and fruits, the concentration of which increased as a function of time (3). The concentration of this compound seemed to be localized in and around the infected areas. The compound was first detected $40 \mathrm{~h}$ after inoculation and prior to the expression of any symptoms of the disease.

A steady accumulation of compound 2 (Fig. 4B) indicates that this may also be a phytoalexin. Transient increases in the concentrations of compounds 3 to 6 (Fig. 4C to F) are an indication that these may be intermediary metabolites produced in the plantpathogen interaction.

Recent investigations on fungus-infected sapwood tissues of various members of Rosaceae reported the formation of biphenyl $(27,29)$ and dibenzofuran derivatives (28) possessing antifungal activities. Various Malus cultivars were also reported to produce such biphenyl derivatives as aucuparin, 2'-methoxyaucuparin, and 4'methoxyaucuparin (26). While in the woody tissues of Malus cultivars, only biphenyl compounds were reported, such closely related members of Rosaceae as Pyrus and Sorbus apparently accumulated only dibenzofurans. The accumulation of biphenyls and benzofurans have been reported to be mutually exclusive. The authors were unable to detect the simultaneous accumulation of both classes of compounds in any members of Rosaceae they investigated.

Although cell suspension cultures cannot be used to investigate the tissue-specific or subcellular site of accumulation of phytoalexins, accumulation of a compound in the growth medium is an indication that, in intact plants, this is transported to the cell wall/ intercellular spaces. Incubation of $V$. inaequalis spores in the presence of malusfuran and its aglycone indicated a significantly higher fungitoxicity of the latter. We do not know, currently, in which form malusfuran acts. Preliminary experiments indicated that $V$. inaequalis has a $\beta$-glucosidase that is detectable during spore germination. Treatment of malusfuran with an almond $\beta$-glucosidase preparation released its aglycone. Therefore, it is possible that malusfuran produced in response to invasion by $V$. inaequalis is

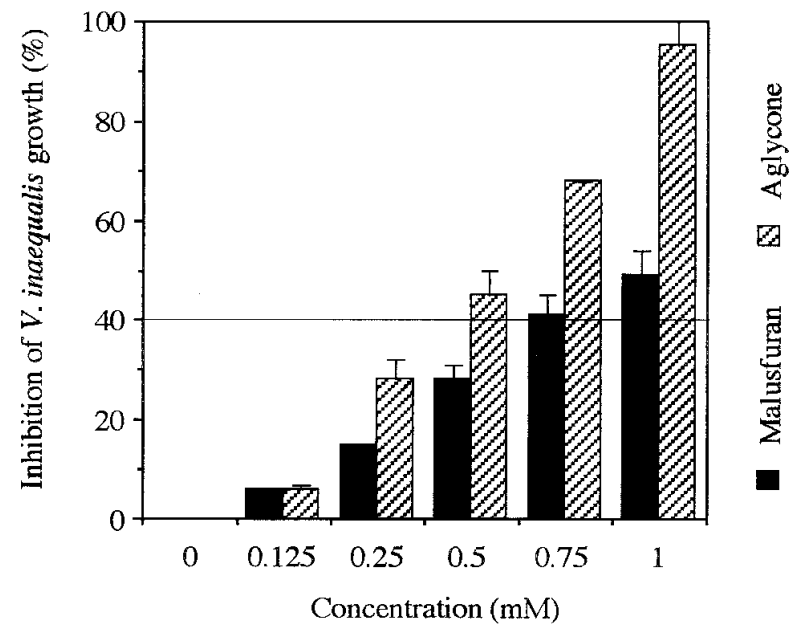

Fig. 8. Effect of increasing concentrations of malusfuran and its aglycone on mycelial growth of Venturia inaequalis after 7 days. Experimental details are given in Materials and Methods. Bars indicate \pm standard error. hydrolyzed, and the product, the dibenzofuran derivative, inhibits further spore germination and hyphal growth, arresting further invasion. The aglycone of malusfuran may also be produced by another mechanism. The presence of a UDPglucose/coniferyl alcohol glucosyl-transferase with a reversible reaction has been reported from spruce tissues (46). Alternately, the aglycone of malusfuran may be produced by such a reversible, cell wall-localized glucosyltransferase. Since the penetration of $V$. inaequalis germ tubes has been observed to occur directly over the junction of epidermal cells (33), accumulation of malusfuran in the intercellular spaces may represent a possible mechanism to counter fungal invasion in early stages of the infection. Similar data were found with phytoalexins extracted from cucumber plants (10).

Phytoalexins have been suggested repeatedly to play a role in plant defenses against microbial invasion (14). In many cases of incompatible host-pathogen interaction, there is a good correlation between the degree of host resistance and the level of phytoalexin accumulation (44). Not all plant-pathogen interaction can be easily described as either compatible or incompatible. In some of these interactions, phytoalexin accumulation correlates with resistance. This seems to be the case with 'Liberty' apple cell cultures that are resistant to invasion by $V$. inaequalis, the scab-causing organism, in which malusfuran concentrations reach levels that were reported for other plant cell cultures (13).

As with other incompatible plant-pathogen interactions, it is unlikely that accumulation of malusfuran is the sole cause of resistance. It is more likely that malusfuran production is one of the many components of the resistance principle of apples against $V$. inaequalis.

\section{ACKNOWLEDGMENTS}

This research was supported by the Cornell Biotechnology Program, which is sponsored by the New York State Science and Technology Foundation and a consortium of industries. We thank W. Koeller and $\mathrm{H}$. L. Gustafson for the Venturia inaequalis cultures and spores, and $\mathrm{K}$. Arnink for the sugar determination.

\section{LITERATURE CITED}

1. Aderhold, R. 1902. Ein Beitrag zur Frage der Empfindlichkeit der Apfelsorten für Fusicladium dendriticum (Wakkr.) Fekl. und deren Beziehungen zum Wetter. Arb. Kais. Biol. Anst. Land. Forstwirtsch. 2:560-566.

2. Apostol, I., Low, P. S., Heinstein, P., Stipanovic, R. D., and Altman, D. W. 1987. Inhibition of elicitor-induced phytoalexin formation in cotton and soybean cells by citrate. Plant Physiol. 84:1276-1280.

3. Barnes, E. H., and Williams, E. B. 1960. A biochemical response of apple tissues to fungus infection. Phytopathology 50:844-846.

4. Barz, W., Daniel, S., Hinderer, W., Jaques, U., Kessmann, H., Köster, J., Otto, C., and Tiemann, K. 1988. Elicitation and metabolism of phytoalexins in plant cell cultures. Pages 178-198 in: Application of Plant Cell and Tissue Culture (Ciba Foundation Symposium). John Wiley \& Sons, Chichester, England.

5. Borejsza-Wysocki, W., and Hrazdina, G. 1994. Biosynthesis of p-hydroxyphenylbutan-2-one in raspberry fruits and tissue cultures. Phytochemistry 35:623-628.

6. Borejsza-Wysocki, W., and Hrazdina, G. 1994. Establishment of callus and cell suspension cultures of raspberry (Rubus idaeus cv. Royalty). Plant Cell Tissue Organ Cult. 37:213-216.

7. Borejsza-Wysocki, W., and Hrazdina, G. 1996. Aromatic polyketide synthases-Purification, characterization, and antibody development to benzalacetone synthase from raspberry fruits. Plant Physiol. 110:791-799.

8. Bradfield, A. E., Flood, A. E., Hulme, A. C., and Williams, A. H. 1952. Chlorogenic acid in fruit trees. Nature 170:168-169.

9. Breitmaier, E., and Voelter, W. 1987. Carbon-13 NMR Spectroscopy: High Resolution Methods and Application in Organic Chemistry and Biochemistry. VCH Pubs. Inc., New York.

10. Daayf, F., Schmitt, A., and Belanger, R. R. 1997. Evidence of phytoalexins in cucumber leaves infected with powdery mildew following treatment with leaf extracts of Reynoutria sachalinensis. Plant Physiol. 113:719-727.

11. Daniel, S., and Barz, W. 1990. Elicitor induced metabolic changes in cell cultures of chickpea (Cicer arietinum L.) cultivars resistant and suscep- 
tible to Ascochyta rabiei. II. Differential induction of chalcone synthase mRNA activity and analysis of in-vitro-translated protein patterns. Planta 182:279-286.

12. Dietrich, A., Mayer, J. E., and Hahlbrock, K. 1990. Fungal elicitor triggers rapid, transient, and specific protein phosphorylation in parsley cell suspension cultures. J. Biol. Chem. 265:6360-6368.

13. Dixon, R. A. 1980. Plant tissue culture methods in the study of phytoalexin induction. Pages 186-196 in: Tissue Culture Methods for Plant Pathologists. D. S. Ingram and J. P. Helgeson, eds. Blackwell Scientific Publications Ltd., Oxford.

14. Dixon, R. A., Choudhary, A. D., Dalkin, K., Edwards, R., Fahrendorf, T., Gowri, G., Harrison, M. J., Lamb, C. J., Loake, G. J., Maxwell, C. A., Orr, J., and Paiva, N. L. 1992. Molecular biology of stress induced phenylpropanoid and isoflavonoid biosynthesis in alfalfa. Recent Adv. Phytochem. 26:91-138.

15. Ernst, L., Wray, V., Chertkov, V. A., and Sergeyev, N. M. 1977. Highresolution proton-coupled ${ }^{13} \mathrm{C}$-NMR spectra of monosubstituted benzenes: Theoretical empirical correlations of Jch. J. Magn. Reson. 25:123-139.

16. Fischer, D., Ebenau-Jehle, C., and Grisebach, H. 1990. Phytoalexin synthesis in soybean: Purification and characterization of NADPH:2'hydroxydaidzein oxidoreductase from elicitor-challenged soybean cell cultures. Arch. Biochem. Biophys. 276:390-395.

17. Gianfranceschi, L., McDermott, J. M., Seglias, N., Koller, B., Kellerhals, M., and Gessler, C. 1994. Towards a marker assisted breeding for resistance against apple scab. Euphytica 77:93-96.

18. Grisebach, H., and Hahlbrock, K. 1974. Enzymology and regulation of flavonoid and lignin biosynthesis in plants and plant cell suspension cultures. Pages 667-723 in: Metabolism and Regulation of Secondary Plant Products. V. C. Runeckles and E. E. Conn, eds. Academic Press, New York.

19. Hinderer, W., Flentje, U., and Barz, W. 1987. Microsomal isoflavone 2'and 3'-hydroxylases from chickpea (Cicer arietinum L.) cell suspensions induced for pterocarpan phytoalexin formation. FEBS (Fed. Eur. Biochem. Soc.) Lett. 214:101-106.

20. Hurd, R. E., and John, B. K. 1991. Gradient-enhanced proton-detected heteronuclear multiple-quantum coherence spectroscopy. J. Magn. Reson. 91:648-653.

21. Hutchinson, A., Taper, C. D., and Towers, G. H. N. 1959. Studies on phloridzin in Malus. Can. J. Biochem. Biophys. 37:901-910.

22. Kellerhals, M. 1989. Breeding of pome fruits with stable resistance to disease. Pages 116-129 in: Integrated Control of Pome Fruit Diseases II. C. Gessler, D. Butt, and B. Koller, eds. OILB-WPRS Bull. XII/6.

23. Kellerhals, M., and Meyer, M. 1994. Combining stable disease resistance with high fruit quality and good yielding capacity in apple. Norw. J. Agric. Sci. Suppl. 17:39-48.

24. King, G. J. 1994. Progress in mapping agronomic genes in apple (The European Apple Genome Mapping Project). Euphytica 77:65-69.

25. Kirkham, D. S. 1957. Studies on the significance of polyphenolic host metabolites in the nutrition of Venturia inaequalis and Venturia pirina. J. Gen. Microbiol. 17:120-134.

26. Kokubun, T., and Harborne, J. B. 1995. Phytoalexin induction in the sapwood of plants of the Maloideae (Rosaceae): Biphenyls or dibenzofurans. Phytochemistry 40:1649-1654.

27. Kokubun, T., Harborne, J. B., Eagles, J., and Waterman, P. G. 1995. Dibenzofuran phytoalexins from the sapwood of Cotoneaster acutifolius and five related species. Phytochemistry 38:57-60.

28. Kokubun, T., Harborne, J. B., Eagles, J., and Waterman, P. G. 1995. Dibenzofuran phytoalexins from the sapwood tissue of Photinia, Pyracantha and Crategus species. Phytochemistry 39:1033-1037.

29. Kokubun, T., Harborne, J. B., Eagles, J., and Waterman, P. G. 1995. Antifungal biphenyl compounds are the phytoalexins of the sapwood of Sorbus aucuparia. Phytochemistry 40:57-59.

30. Korban, S. S., and Morrisey, J. M. 1989. Scab-resistant apple cultivars. Fruit Var. J. 43:48-50.

31. Low, P. S., and Heinstein, P. F. 1986. Elicitor stimulation of the defense response in cultured plant cells monitored by fluorescent dyes. Arch.
Biochem. Biophys. 249:472-479.

32. Mabry, T. J., Markham, K. R., and Thomas, M. B. 1970. The Systematic Identification of Flavonoids. Springer Verlag, New York.

33. MacHardy, W. E. 1996. Apple Scab-Biology, Epidemiology and Management. The American Phytopathological Society, St. Paul, MN.

34. Mansfield, J. W., and Bailey, J. A. 1982. Phytoalexins: Current problems and future prospects. Pages 319-323 in: Phytoalexins. J. A. Bailey and J. W. Mansfield, eds. John Wiley \& Sons, New York.

35. McLafferty, F. W. 1967. Interpretation of Mass Spectra. W. A. Benjamin, Inc., New York.

36. Messner, B., Boll, M., and Berndt, J. 1991. L-Phenylalanine ammonialyase in suspension culture cells of spruce (Picea abies). Induction by UV-light and fungal elicitor. Plant Cell Tissue Organ Cult. 27:267-274.

37. Murashige, T., and Skoog, F. 1962. A revised medium for rapid growth and bioassay with tobacco tissue culture. Physiol. Plant 15:473-497.

38. Oydvin, J., and Richardson, D. G. 1987. A paper chromatographic survey of the phenol content of apple peel from scab resistant and scab susceptible genotypes. Norw. J. Agric. Sci. 1:7-13.

39. Panichpol, K., and Waterman, P. G. 1978. Novel flavonoids from the stem of Popowia cauliflora. Phytochemistry 17:1363-1367.

40. Parisi, L., Lespinasse, Y., Guillaumes, J., and Krüger, J. 1993. A new race of Venturia inaequalis virulent to apples with resistance due to the Vf gene. Phytopathology 83:533-537.

41. Park, H.-H., Hakamatsuka, T., Sankawa, U., and Ebizuka, Y. 1995 Rapid metabolims of isoflavonoids in elicitor-treated cell suspension cultures of Pueraria lobata. Phytochemistry 38:373-380.

42. Pellizzari, E. D., Kuc, J., and Williams, E. B. 1970. Hydrolytic activity in supernatant from germinated spores of Venturia inaequalis. Phytopathology 60:389-390.

43. Richmond, D. V., and Martin, J. T. 1959. Studies on plant cuticles. III. The composition of cuticles of apple leaves and fruits. Ann. Appl. Biol. 47:583-592.

44. Rogers, E. E., Glazebrook, J., and Ausubel, F. M. 1996. Mode of action of the Arabidopsis thaliana phytoalexin camalexin and its role in Arabidopsis-pathogen interactions. Mol. Plant-Microbe Interact. 9:748-757.

45. Ruiz-Cabello, J., Vuister, W., Moonen, C. T., van Gelderen, P., Cohen, J. S., and van Zijl, P. C. M. 1992. Gradient-enhanced heteronuclear correlation spectroscopy: Theory and experimental aspects. J. Magn. Reson. 100:282-383.

46. Schmid, G., and Grisebach, H. 1982. Enzymatic synthesis of lignin precursors: Purification and properties of UDPglucose:coniferylalcohol glucosyltransferase from cambial sap of spruce (Picea abies L.). Eur. J. Biochem. 123:363-370.

47. Stoessl, A. 1982. Biosynthesis of phytoalexins. Pages 133-180 in: Phytoalexins. J. A. Bailey and J. W. Mansfield, eds. John Wiley \& Sons, New York.

48. Tiemann, K., Inzé, D., van Montague, M., and Barz, W. 1991. Pterocarpan phytoalexin biosynthesis in elicitor-challenged chickpea (Cicer arietinum L.) cell cultures. Purification, characterization and cDNA cloning of NADPH:isoflavone oxidoreductase. Eur. J. Biochem. 200: 751-757.

49. Weeden, N. F., Hemmat, M., Lawson, D. M., Lodhi, M., Bell, R. L., Manganaris, A. G., Reisch, R. I., Brown, S. K., and Ye, G.-N. 1994. Development and application of molecular marker linkage maps in woody fruit crops. Euphytica 77:71-75.

50. Williams, A. H. 1955. Phenolic substances of pear-apple hybrids. Nature 175:213.

51. Williams, A. H. 1956. A new dihydrochalcone from Malus species. Chem. Ind. 1306.

52. Williams, A. H. 1960. The distribution of phenolic compounds in apple and pear trees. Page 131 in: Phenolics in Plants in Health and Disease. J. B. Pridham, ed. Pergamon Press, New York.

53. Williams, A. H. 1961. Dihydrochalcones of Malus species. J. Chem. Soc. 4:33-36.

54. Williams, E. B., and Kuc, J. 1969. Resistance in Malus to Venturia inaequalis. Annu. Rev. Phytopathol. 7:223-246. 